\title{
Cortázar en Busca de uno de sus Personajes
}

En "La barca o nueva visita a Venecia"1, Cortázar se propone la difícil tarea de reescribir un texto suyo que data de 1954 sin modificar lo ya escrito, salvo algunos retoques estilisticos, merced a la insersión en bastardillas de los comentarios de uno de los personajes del cuento, Dora. En el prefacio nos advierte que:

Si Dora hubiera pensado en Pirandello, desde un principio hubiera venido o buscar al autor para reprocharle su ignorancia o su persistente hipocresía. Pero soy yo quien va ahora hacia ella para que finalmente ponga las cartas boca arriba. Dora no puede saber quién es el autor del relato, y sus críticas se dirigen solamente a lo que en éste sucede visto desde adentro, allï donde ella existe; pero que ese suceder sea un texto y ella un personaje de su escritura no cambian en nada su derechosigualmente textual a rebelarse frente a una crónica que juzga insuficiente o insidiosa. (p. 110)

Bueno, Dora también hubiera podido pensar en Cervantes o en Unamuno. . . pero tratándose de un relato que tiene lugar en Italia, Pirandello viene más al caso. Lo importante es ver cómo la transformación de un personaje que no es sino "comparsa" (p. 111) en crítica del texto y por ende de su contenido, lo altera prestándole una pluridimensionalidad que estaba totalmente ausente del texto original escrito exclusivamente en tercera persona o. sea exclusivamente visto desde la tradicional objetividad de un "Deus ex machina". 
Dora es muchas cosas. Dora son los veintitrés años que separan al autor de "La barca" del de "Usted se tendió a tu lado" otro de los cuentos incluidos en el último volumen de Cortázar. Dora le permite al autor reî́rse de su propio texto sin destruirlo, conservando lo esencial del mismo, el tema del amor y de la muerte. Algunos pasajes, algunas frases parecerỉan como excesivamente románticos, casi cursis - telenovelescos sin la intervención de Dora quien, al hacernos sonreír, convierte al texto "anterior" en absolutamente necesario:

'Escucha con la boca', había pensado Valentina cuando del primer diálogo nació una invitación a beber el famoso coctel del bar, que Adriano recomendaba y que Beppo, agitándolo en un cabrilleo de cromos, proclamaba la joya de Roma, el Tirreno metido en una copa con todos sus tritones y sus hipocampos. Ese día Dora y Valentina encontraron simpático a Adriano,

$\mathrm{Hm}$.

no parecía turista (él se consideraba un viajero y acentuaba sonriendo el distingo) y el diálogo de mediodía fue un encanto más de Roma en abril. Dora lo olvidó en seguida.

Falso. Distinguir entre savoir faire y tilinguería. Nadie como yo (o Valentina claro) podia olvidar asi nomás a alguien como Adriano; pero me sucede que soy inteligente y desde él vamos sentí que mi largo de onda no era el suyo. Hablo de amistad, no de otra cosa porque en eso ni siquiera se podia hablar de ondas. Y puesto que no quedaba nada posible, ¿para qué perder el tiempo? (p. 113)

Al principio del cuento la relación entre el lector, el texto "original" y los comentarios de Dora que introducen un segundo texto, le permiten al primero esconderse detrás de las réplicas de Dora. Esta se convierte, pues, en una especie de máscara del lector que le permitirá identificarse con los protagonistas sin experimentar la más minnima culpabilidad frente a un exceso de sentimentalismo incompatible con su "persona". El humor restablece el equilibrio del texto y de su relación con un lector acostumbrado a "otro" Cortázar. En otras ocasiones el sentido del humor de Dora simplemente nos regocija como en tantos otros cuentos de Cortázar:

Valentina miró una y otra vez la boca de Adriano, la miraba al desnudo en ese momento en que el tenedor lleva la 
comida a los labios que se apartan para recibirla, cuando no se debe mirar. Y él lo sabỉa y apretaba en la boca el trozo de pulpo frito como si fuera una lengua de mujer, como si ya estuviera besando a Valentina.

(...) dicho de paso, también hay ahi un plagio avant la lettre de una famosa escena de Tom Jones en el cine. (p. 114)

A veces, claro, el lector se pregunta si existió en realidad ese texto sin los comentarios de Dora, escrito hace más de veinte años o si el texto que leemos no sería una variante de la primera frase del cuento: "El turismo juega con sus adeptos, ..." (p. 111), a saber "Cortázar juega con sus adeptos,..." pero, de todas formas, lo interesante es la crítica del texto dentro del texto mismo, la fisura que el humor crea dentro de un texto lineal y tradicional pero no falto de poesia, que a su vez obliga al lector a adoptar el tipo de objetividad crítica en el que Brecht tanto insistiera.

Dora le permite también al autor convertir a una Valentina un poco "a la Corin Tellado" en un ser humano, en una mujer que trata de llenar el vacǐo que ha dejado en ella un fracaso matrimonial y que tiene miedo de volver a entregarse, de continuar con esa perpetua dialéctica de eros y de thanatos que anuncia con segura intermitencia nuestra propia muerte. Dora anota la siguiente confidencia de Valentina: "vos no me conocés, Dora, no tenés idea de lo que me anda por dentro, este vacio lleno de espejos" (...) (p. 116).

Dora es también una suerte de alter ego de Valentina. El texto "original" supone que no es sino una compañera de viaje encargada del itinerario turístico. Un "patito feo" sin importancia. Sin embargo la Dora dentro del texto, pero exterior al texto original, parece conocer demasiado bien a su compañera de viaje:

.. todo era tan claro para mi, Valentina Piuma al Vento, la Neura y la Depre y doble dósis de valium por la noche, è viejo, viejo cuadro de nuestra joven época. Una apuesta conmigo mismo (sic) (...) (p. 121-123)

Nos da la impresión de ser el doble de Valentina. La turista "responsable" y metódica que quiere gozar del viaje tranquilamente sin tener que complicarse la vida con la "otra" Valentina que ve en los encuentros masculinos una suerte de fuga. . aún cuando quisiera, en un momento del texto "original" que fuera para siempre, porque los "parasiempres" son ficticios talismanes contra la muerte. 
Como lectora (y crítica) del texto original, Dora se transforma también en personaje activo, deja de ser mera comparsa, añadiendo una tercera dimensión a la trama del cuento. A través de sus comentarios introduce un triángulo amoroso, apenas apuntado en el primer texto: "Sentìa (Adriano) celos de Dora, los disimulaba apenas..." (p. 115). Es Dora quien siente ahora celos de Adriano y del gondolero Dino. Celos que nos ayudan a comprender la súbita aparición de Adriano en Venecia después de la aventura de Valentina con Dino, ya que nos enteramos de que Dora le ha telefoneado con el propósito implícito de provocar una escena que le devuelva eventualmente a Valentina. O sea que Dora modifica no solamente nuestra interpretación de lo escrito sino también de la trama que a su vez modifica el contenido del cuento, pero siempre a partir de "intuiciones" que el primer texto despierta en el hipotético lector de ese texto que no es sino el autor, añadiendo, cambiando, puliendo su propio texto a través de los comentarios de Dora.

Como en un juego de espejos, Dora le permite a Cortázar establecer nuevas convergencias y divergencias, nuevas posibilidades. Produce un "déclenchement" en el sentido que Derrida le da a este término en La Dissémination, que multiplica los niveles del texto. Por ejemplo, Dora, al proyectar sus propios deseos homosexuales sobre Valentina, anota:

Hm. ¿Por qué le iba mal con los hombres? Mientras piensa cómo se la hace pensar, hay como la imagen de algo acorralado, sitiado: la verdad profunda, cercada por las mentiras de un conformismo irrenunciable. Pobrecita, pobrecita. (p. 129)

Pero, irónicamente, al utilizar el artificio de Dora, Cortázar ha desplazado al lector, al crítico, al espectador. Dora es también nosotros, los lectores. Cortázar nos introduce en el cuento y nos desarma. Nadamos en pleno texto, en plena literatura, dejamos de contribuir, desaparecemos. Ya en Rayuela Cortázar habỉa introducido la multiplicidad de lecturas, pero en esa gran novela presentaba al lector con una variedad de opciones sin acorralarlo. El lector no es Morelli ni es ninguno de los personajes, puede jugar, pero no existe por parte del autor la intención de atraparlo... En "La barca", por el contrario, la trampa es perfecta. . .desde el prefacio. Nuestra reacción es, efectivamente, automática. Aún antes de leer el texto del cuento ya nos previene Cortázar que éste le parece malo...pero que le gusta 
"tanto". Nos dice que el texto es falso: "porque pasa al lado de una verdad que entonces no fuil capaz de aprehender y que ahora me parece evidente." (p. 110)

El adepto(a), y yo soy una de ellas, empieza por querer encontrar algo que le guste en el texto "original"...pero éste materialmente no se puede leer sin los comentarios de Dora, o sea sin hacer trampa, y sin caer en la trampa..."No es un cuento de Cortázar. . .no puede ser un cuento de Cortázar. . . pero sî, con Dora es un cuento de Cortázar..." Y Dora nos obliga a meternos en el inter-texto, en el tejido de alusiones, de imágenes, de lugares comunes que eventualmente se convertirán en La Muerte. . .en el fin de toda dialéctica, de toda contribución "viva" al texto. . .en la aceptación de la "golondrina", o sea de nuestro destino, que es la muerte.

Valentina sabe que "También Adriano es la muerte" (p. 124) ya que todo "lo que se posee es la muerte porque anuncia la desposesión, organiza el vacío a venir" (p. 125), pero también nos dice que "haber pensado eso valía tan solo como una metáfora puesto que renunciar a Adriano mataria algo en ella, la arrancarìa a una parte momentánea de sí misma,..." (p. 124). Trata de huir de esta dialéctica quizá demasiado trillada (pero no por ello menos cierta) con un: "Refranes infantiles, mantariru liru la,..." (p. 125). La tensión entre el vacio y la nada que llamamos vida se adelgaza súbitamente: "Sabía.. que Adriano no cambiaria su vida por ella, Osorno por Buenos Aires." (p. 125); y una vez más Dora nos ayuda a comprenderla apuntando la "mala fe" (en el sentido existencialista del término) de Valentina:

¿Cómo podía saberlo? Todo apunta en la dirección contraria; es Valentina la que jamás cambiaria Buenos Aires por Osorno, su instalada vida, sus rutinas rioplatenses. En el fondo no creo que ella pensara eso que le hacen pensar; también es cierto que la cobardia tiende a proyectar en otros la propia responsabilidad, etcétera. (p. 125)

Esa tensión se desvanece en el preciso momento en que la golondrina muerta cae a los pies de Valentina: "fulminada en un aire que de pronto, esquivo y cruel, había dejado de sostenerla." (p. 126)

A partir de ese momento empezará la fuga de Valentina que la llevará a Venecia, verdadera metáfora de la unión de eros y de thanatos. Venecia y sus canales secretos, Venecia-mausoleo... Y Dino, gondolero de la muerte, remero del Styx que desemboca en la otra orilla, en la Fondamenta Nuove, en el cementerio. Su aventura 
con Dino, su erotismo sin ambages, ni futuro, ni sentimentalismo, ni "para siempres" al abrir las compuertas de la libertad le revelan también su propia muerte. Quizá su incapacidad de soportar ese estado de incertidumbre y tensión que produce esa indefinible ansiedad que es sintoma de vida se revelen por última vez durante su primer paseo en Góndola que la conduce inexorablemente al lecho de Dino:

Mirando otra vez hacia proa, Valentina vió venir un pequeño puente. Ya antes se habìa dicho que sería delicioso el instante de pasar por debajo de los puentes, perdiéndose un momento en su concavidad rezumante de moho, imaginando a los viandantes en lo alto, pero ahora vió venir el puente con una vaga angustia como si fuera la capa gigantesca de un arcón que iba a cerrarse sobre ella. Se obligó a guardar los ojos abiertos en el breve tránsito, pero sufrió, y cuando la angosta raja de cielo brillante surgió nuevamente sobre ella, hizo un confuso gesto de agradecimiento. . .; de pronto necesitaba estar cerca de alguien vivo y ajeno a la vez, mezclarse en un diálogo que la alejara de esa ausencia, de esa nada que le viciaba el día y las cosas. (p. 133)

Pavor del retorno al gene, al vientre materno, a la nada que ya Dora había presentido que la habitaba desde el principio del relato:

Me cuesta imaginar que Adriano, por masculinamente ciego que estuviera, no alcanzara a sospechar que Valentina estaba besando la nada en su boca, que antes y después del amor Valentina seguiría llorando en sueños. (p. 116)

Evidentemente la parte inferior del puente podrỉa también simbolizar al sexo femenino y Dora así lo ve desde su perspectiva homosexual:

.. Tal vez la ausencia de Adriano ganaba peso en Valentina, pero una vez más como la máscara de otra distancia, de otra carencia que ella no queria o no podía mirar cara a cara. (Wishful thinking, acaso; pero, ¿y la celebérrima intuición femenina? La noche en que tomamos al mismo tiempo un pote de crema y mi mano se apoyó en la suya, y nos miramos... ¿Por qué no completé la caricia que el azar empezaba? De alguna manera todo quedó como suspendido en el aire, entre nosotras, y los paseos en góndola 
son, es sabido, exhumadores de semisueños, de nostalgias y recuentos arrepentidos.) (p. 134)

Dora le permite también a Cortázar introducir en el cuento un elemento de ilusión dramática. Los comentarios de Dora están hechos en primera persona y como escribe Derrida:

Dans cette échéance aux arêtes nombreuses, celui que dit je au présent, dans l'évènement dit positif de son discours ne saurait avoir que l'illusion de la maîtrise. Alors même qu'il croit conduire les opérations, à chaque instant et malgré lui sa place-l'ouverture au présent de quiconque croit pouvoir dire je, je pense, je suis, je vois, je sens, je dis (vous, par exemple, ici, maintenant)-est decidée par un coup de dés dont le hasard développe ensuite inexorablement la loi.

o sea que el elemento ${ }^{2}$ de intimidad que aporta la añadidura de la crítica de "Dora" al primer texto, aún cuando representa una apertura que le permite al autor multiplicar las facetas del texto, se convierte también en otro elemento del juego literario, del drama que se está desarrollando bajo los ojos del lector.

El personaje de Dora, al rebelarse en contra del texto "original" nos da a nosotros los lectores "externos" la impresión de que ella controlaba el desarrollo de la acción mucho más de lo que el "primer" texto intimaba, sobre todo después de la llamada telefónica a Adriano. Sin embargo, las intrigas de Dora y la presencia de Adriano en Venecia no alteran en lo más minimo la conclusión del cuento, solo contribuyen a enmarcarlo con mayor nitidez en el esquema original del autor. Es a partir de ese esquema original, de ese primer texto que Dora va a reaccionar, y como se le hace reaccionar como lectora (que también fue protagonista-comparsa del drama original) y que se expresa en primera persona, es igualmente necesario que sus reacciones sean subjetivas, emocionales. El texto mismo produce el primer "déclenchement" (el comentario sobre la mirada de Valentina) que va a ir moldeando, inexorablemente, a Dora como lectora, creando la ilusión de que ha usurpado nuestro papel además de haber modificado el texto anterior, lo cual en el fondo es también una ilusión, que es la verdad. . .del texto.

Si pudiéramos hablar de un primer texto y de un segundo texto en "La barca o nueva visita a Venecia", el primer texto narra algo que ningún viajero desconoce: los encuentros fortuitos, los romances 
más o menos desgarradores pero rara vez terminales que el turismo propicia. En el caso de Adriano y de Valentina el lector podrìa suponer que tienen algo en común ya que ambos son sudamericanos, y más específicamente del cono sur. De igual modo, la aventura de Valentina con el gondolero Dino debe responder a las fantasías eróticas de más de una turista de clase media y algo emancipada, como supongo que responderá a la de muchos gondoleros. Por otro lado Dora -la primera Dora - responde a otro lugar común: El de la compañera de viaje meticulosa, ordenada, que no representa ningún peligro para la heroína por no haber sido igualmente dotada por la naturaleza.

Lo interesante es que, a partir de una infraestructura tan aparentemente débil o trillada, haya surgido un primer texto que traza los primeros pasos de una mujer en vǐas de liberarse con sus opciones $\mathrm{y}$ sus peligros y su fracaso final, y un segundo texto que no sugiere otras opciones sino otras motivaciones de indole freudiana, pero en realidad totalmente gratuitas ya que el tex to "original" no corrobora en nada las sospechas que Dora alberga sobre las inclinaciones lesbianas de Valentina. Dora proyecta sus propias tendencias y nos da una interpretación subjetiva de los hechos con la intención, claro, de parecer objetiva. El personaje de Dora le permite pues a Cortázar introducir la ilusión de la objetividad crítica. Afortunadamente el tener conciencia de que se trata de una ilusión no destruye esta ilusión y éste es el mérito mayor del cuento.

Tufts University

MONIQUE LEMAITRE

\section{NOTAS}

1. Julio Cortázar, Alguien que anda por ahi, Ediciones Alfaguara, Madrid, 1977. Todas las citas de "La barca" serán de esta edición y las páginas estarán citadas en el texto.

2. Jacques Derrida, La Dissémination, Collection "Tel Quel", Seuil, 1972, pp. 330-331. 